\title{
RANCANG BANGUN SISTEM PEMADATAN PADA MESIN PRES BATAKO
}

\author{
Abdur Rohim \\ Fakultas Teknik, Program Studi Teknik Mesin \\ Universitas Muria Kudus \\ Email: rohim583@gmail.com \\ Qomaruddin \\ Fakultas Teknik, Program Studi Teknik Mesin \\ Universitas Muria Kudus \\ Email: qomaruddin@umk.ac.id \\ Rochmad Winarso \\ Fakultas Teknik, Program Studi Teknik Mesin \\ Universitas Muria Kudus \\ Email: rochmad.winarso@umk.ac.id
}

\begin{abstract}
ABSTRAK
Kemajuan teknologi yang mengalami perkembangan yang sangat pesat berimbas pada kehidupan manusia untuk membantu atau mempermudah dalam kehidupan manusia, salah satunya adalah press batako. Tujuan dari rancang bangun pemadat pada mesin press batako 10 biji sekali cetak ini di harapkan dapat memaksimalkan proses pembuatan batako dan mempermudah dalam pemadatan bahan batako. Metode yang digunakan pada proses perancangan ini tinjauan pustaka berupa system pemadatan yang meliputi; perhitungan motor, perhitungan getaran, proses perancangan atau design untuk menentukan dimensi serta matrial yang akan di gunakan. Berikutnya dilakukan proses perakitan, finishing dan uji coba. Hasil akhir dari rancang bangun sistem pemadat ini adalah menggunakan motor listrik 2HP dengan kecepatan $700 \mathrm{rpm}$ ditransmisikan menjadi $700 \mathrm{rpm}$ menggunakan puli dengan diameter 3inc dan 3 inc v belt tipe A dengan panjang $653 \mathrm{~cm}$. Waktu yang dibutuhkan dalam pengerjaan adalah 493 menit, finishing adalah 60 menit dan proses perakitan adalah 210 menit dengan sistem pemadatan ini mampu memadatkan 10 buah batako dalam 1 kali prosesnya.
\end{abstract}

Kata kunci: press batako, sistem pemadatan, getaran.

\begin{abstract}
Technological advances that experience rapid development impact on human life to help or facilitate human life, one of which is press brick. The purpose of the design of compactors on the press machine for 10-piece brick making is expected to be able to maximize the process of making concrete blocks and simplifying compaction of brick materials. The method used in the design process is a literature review in the form of a compaction system which includes; motor calculation, vibration calculation, design process or design to determine the dimensions and material that will be used. Next is the assembly process, finishing and testing. The final result of the design of the compactor system is to use a 7HP electric motor with a speed of 700rpm transmitted to 700rpm using pulli with a 3 inc diameter and 3 inc vbelt type A with $653 \mathrm{~cm}$ length. The time needed in construction is 493 minutes, finishing is 60 minutes and the assembly process is 210 minutes with a compaction system capable of compacting 10 concrete blocks in one process.
\end{abstract}

Keywords: brick press, compaction system, vibration 


\section{PENDAHULUAN}

Industri bahan bangunan telah berkembang sedemikan pesatnya, didukung dengan peralatan dan kemampuan sumber daya yang memadai dalam menciptakan hasil bahan bangunan yang baik dan bermutu. Pertambahan jumlah penduduk dan tumbuhnya permukiman rumah disetiap daerah membuka peluang bisnis usaha bahan bangunan dalam menyerap pasar yang ada. Kondisi ini merupakan peluang dan tantangan usaha bahan bangunan. Suatu perusahaan bahan banagunan dihadapkan pada perlunya penciptaan daya imajinasi, inovasi dan kreatifitas yang tinggi dan tepat untuk menjawab kebutuhan pasar.

Industri batako press mesin ini sebagai alternatif bahan material lain dalam membangun selain batu bata dengan segmen kelas menengah ke bawah. Dalam persaingan dunia industri menengah, perusahaan dituntut untukberproduksi secara cepat dan efisien agar mencapai produksi sesuai target. Salahsatu upaya yang ditempuh untuk meningkatkan produksi tersebut ialah denganmengubah proses manual menjadi proses mekanik. Disisi lain penerapan sistem kerja mekanik juga dapat mengurangi biaya produksi yang tinggi, karena dapat mempermudah ataupun meringankan beban kerja ketika proses produksi [1]. Hal ini didapatkan dari pengamatan proses cetak batako manual yangkurang efisien dan tidak dapat memenuhi jumlah order dalam skala besar, sehingga dikembangkan menjadi mesin press batako yang labih efisien danmampu memenuhi jumlah order dalam skala besar.

Proses perancangan untuk pembuatan mesin press batako ini membutuhkan bentuk dan ukuran yang tepat atau presisi, karena sistem kerja pada mesin ini yaitu mampu memproduksi 10 batako dengan sekali press. Hal ini yang menjadikan latar belakang untuk merancang dan membuat mesin terebut. Dengan dirancangnya mesin ini diharapkan dapat mempermudah proses dan meningkatkan kapasitas pembuatan batako di dunia industri menengah maupun industri menengah kebawah, karena semakin banyaknya permintaan batako disektor pasar material dan bangunan [2].

Kebutuhan akan batako berkualitas baik sangat meningkat di masyarakat sedangkan proses pembutan batako di pasaran umumnya masih mengunakan manual tangan dan satu persatu dalam mencetaknya dalam hal ini mengakibatkan stok batako kurang [3]. Proses pemadatan dapat menggunakan penggerak motor listrik [4]. Proses pengepresan dapat dilakukan juga dengan menggunakan mekanisme sistem hidrolik [5].

Mengantisipasi kurangnya stok batako dengan mengembangkan alat atau mesin press batako juga membuat rancang bangun mesin press dengan adanya pemadat bahan cetakan dengan motor listrik ini dapat membantu atau mempercepat membuat batako dengan sekali cetak mampu menghasilkan 10 biji batako dan dapat mempersingkat waktu pengerjaannya.

Tujuan dari rancang bangun pemadat pada mesin press batako 10 biji sekali cetak ini di harapkan dapat memaksimalkan proses pembuatan batako dan mempermudah dalam pemadatan bahan batako dengan sistem pemadatan dapat memadatkan campuran matrial dan mampu mencapai target standard produksi sehingga dapat di aplikasikan pada mesin press batako.

\section{METODOLOGI PENELITIAN}

Metode yang digunakan pada proses perancangan ini dimulai dari tinjauan pustaka berupa sistem pemadatan yang meliputi; perhitungan motor, pergitungan getaran, proses perancangan atau design untuk menentukan dimensi serta matrial yang akan di gunakan. Berikutnya dilakukan proses perakitan, finishing dan uji coba. Alur proses rancang bangun sistem pemadatan mesin press batako.

Perancangan sistem pemadatan merupakan suatu langkah untuk menentukan jenis komponen apa saja yang digunakan beserta size dari komponen tersebut hingga di peroleh seberapa maksimal yang didapat dari masing-masing komponen menghasilkan kapasitas dari output yang dihasilkan pada proses permesinan. Berikut pada gambar 1, merupakan design perencanaan pada meisn. 


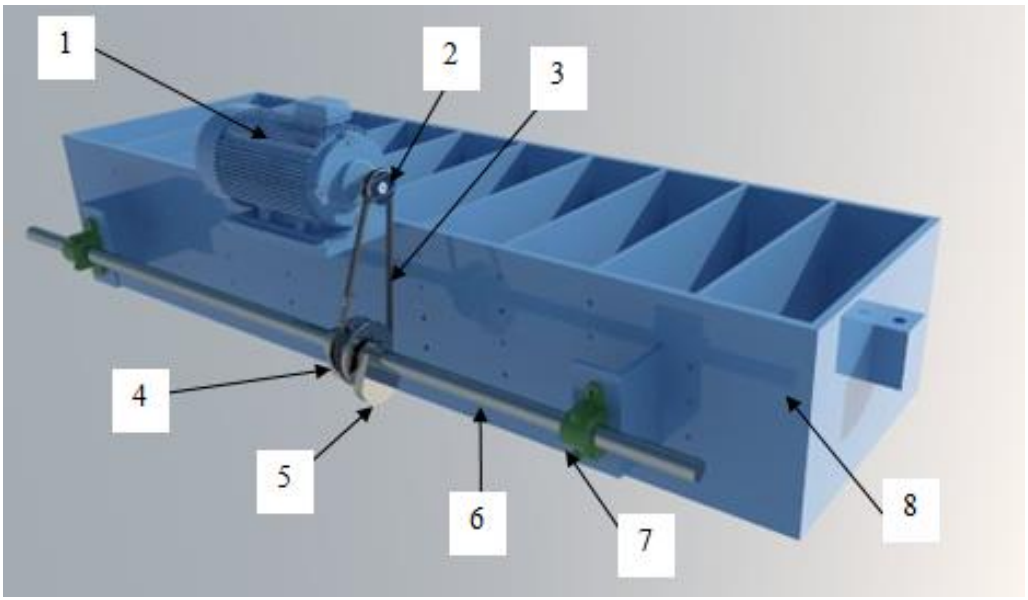

Gambar 1. Mesin Press Batako

Jenis-jenis konponen yang digunakan pada sistem pemadatan melipputi :

1. Motor Penggerak

2. Pulli 1

3. V-belt

4. Pulli 2

5. Bandul

6. Poros

7. Bearing

8. Cetakan

\section{HASIL DAN PEMBAHASAN}

\subsection{Perancangan Spesifikasi}

Perhitungan dalam perancangan spesifikasi didasarkan pada beberapa persamaan sebagaimana pada persamaan 1 dengan hasil pada table 1 sebagai beikut :

Perhitungan kapasitas berdasarkan persamaan 1 sebagai berikut :

$$
\mathrm{mb}_{\mathrm{tot}}=\mathrm{m}_{\mathrm{b} . \mathrm{Z}}
$$

Dengan $\mathrm{m}_{\mathrm{b}}$ adalah beban unit, $\mathrm{z}$ adalah jumlah unit.

Tabel 1 Spesifikasi mesin pemadat

\begin{tabular}{lll}
\hline Bagian & Jenis Perancangan & Hasil \\
\hline Kapasitas & Pembebanan unit & 10 unit/proses \\
& Pembebanan total & $51 \mathrm{~kg}$ \\
\hline
\end{tabular}

\subsection{Perhitungan Motor Listrik}

Perhitungan dalam perancangan motor listrik didasarkan pada beberapa persamaan sebagaimana pada persamaan 2-3 dengan hasil pada table 2 sebagai beikut :

a. Perhitungan torsi mesin (T) dapat di selesaikan dengan persamaan 2 sebagai berikut :

$$
\mathrm{T}=\mathrm{F} \times \mathrm{r}
$$

Dengan $\mathrm{F}$ adalah pembebanan, dan $\mathrm{r}$ adalah jarak pembebanan. 
b. Perhitungan daya mesin (P) dapat di selesaikan dengan persamaan 3 sebagai berikut [6] :

$$
\mathrm{P} \quad=(\mathrm{T} .2 \pi . \mathrm{n}) /(60.1000)
$$

Dengan $\mathrm{n}$ adalah putaran motor.

Pemilihan motor sesuai dengan spesifikasi pada tabel 2

Tabel 2. Pemilihan Motor

\begin{tabular}{lll}
\hline Bagian & Jenis Perancangan & Hasil \\
\hline Motor Listrik & Torsi & $19,45 \mathrm{Nm}$ \\
& Daya & $2 \mathrm{Hp}$ \\
& Rpm & $700 \mathrm{rpm}$ \\
& Frekuensi & $50 \mathrm{~Hz}$ \\
\hline
\end{tabular}

\subsection{Perhitungan Getaran}

Perhitungan dalam perancangan getaran didasarkan pada beberapa persamaan sebagaimana pada persamaan 4-5 dengan hasil pada table 3 sebagai beikut :

a. Perhitungan jumlah getaran $\left(\mathrm{n}_{\mathrm{g}}\right)$ dapat di selesaikan dengan persamaan 4 sebagai berikut :

$\mathrm{F} \quad=\mathrm{n}_{\mathrm{g}} / \mathrm{t}$

Dengan $\mathrm{F}$ adalah frekuensi, $\mathrm{t}$ adalah waktu.

b. Perhitungan periode getaran $\left(\mathrm{T}_{\mathrm{g}}\right)$ dapat di selesaikan dengan persamaan 5 sebagai berikut

$$
\mathrm{T}_{\mathrm{g}}=\mathrm{t} / \mathrm{n}_{\mathrm{g}}
$$

Tabel 3. Perhitungan Getaran

\begin{tabular}{lll}
\hline Bagian & Jenis Perancangan & Hasil \\
\hline Kapasitas & Jumlah getaran & 50getaran/sekon \\
& Periode getaran & 0.02 sekon \\
\hline
\end{tabular}

\subsection{Perhitungan Sistem Transmisi}

Perhitungan dalam perancangan sistem transmisi didasarkan pada beberapa persamaan sebagaimana pada persamaan 5-6 dengan hasil pada table 4 sebagai beikut :

a. Perhitungan kecepatan linear sabuk (v) dapat di selesaikan dengan persamaan 6 sebagai berikut :

b.

$$
\mathrm{V}=\frac{\pi \cdot d p \cdot n 1}{60 \cdot 1000}
$$

Dengan dp adalah diameter puli, $\mathrm{n}_{1}$ adalah kecepatan putar.

c. Perhitungan panjang keliling sabuk (L) dapat di selesaikan dengan persamaan 7 sebagai berikut :

$$
\mathrm{L}=\pi\left(\mathrm{r}_{1}+\mathrm{r}_{2}\right)+2 \cdot \mathrm{Cp}+\frac{(\mathrm{r} 1+\mathrm{r} 2)^{2}}{C_{p}}
$$


Dengan $\mathrm{Cp}$ adalah jarak puli, $\mathrm{r}_{1}$ adalah jari-jari puli.

Pemilihan komponen sistem transmisi seperti pada tabel 4.

Tabel 4. Pemilihan Komponen Sistem Transmisi

\begin{tabular}{lll}
\hline Bagian & Jenis Perancangan & Hasil \\
\hline Puli & Diameter & 3inc \\
& Perbandingan & $1: 1$ \\
Kelt & Kecepatan putar & $700 \mathrm{rpm}$ \\
& Panjang & $762 \mathrm{~mm}$ \\
& Tipe & A \\
& Kecepatan linier & $2,75 \mathrm{~m} / \mathrm{s}$ \\
\hline
\end{tabular}

\subsection{Perhitungan Poros}

Perhitungan dalam perancangan poros didasarkan pada beberapa persamaan sebagaimana pada persamaan 5-6 dengan hasil pada table 4 sebagai beikut :

a. Perhitungan kecepatan linear sabuk (v) dapat di selesaikan dengan persamaan 8 sebagai berikut :

$$
\tau_{\mathrm{a}}=\frac{a b}{s f 1 . s f 2}
$$

Dengan dp adalah diameter puli, $\mathrm{n}_{1}$ adalah kecepatan putar.

b. Perhitungan kecepatan linear sabuk (v) dapat di selesaikan dengan persamaan 9 sebagai berikut :

$$
\tau_{\text {maks }} \quad=\frac{6}{\pi d^{3}} \sqrt{(K m, M)^{2}+(K t . T)^{2}}
$$

Dengan dp adalah diameter puli, $\mathrm{n}_{1}$ adalah kecepatan putar.

c. Perhitungan panjang keliling sabuk (L) dapat di selesaikan dengan persamaan 10 sebagai berikut :

Ds $\quad \geq\left[\left(\frac{5 \cdot 1}{\text { тa }}\right) \sqrt{(K m \cdot M)^{2}+(K t \cdot T)^{2}}\right]^{\frac{1}{a}}$

Dengan $\mathrm{Cp}$ adalah jarak puli, $\mathrm{r}_{1}$ adalah jari-jari puli.

Pemilihan poros ditunjukkan pada tabel 5.

Tabel 5. Pemilihan Poros

\begin{tabular}{lll}
\hline Bagian & Jenis Perancangan & Hasil \\
\hline Puli & Diameter & 3inc \\
& Perbandingan & $1: 1$ \\
Belt & Kecepatan putar & $700 \mathrm{rpm}$ \\
& Panjang & $762 \mathrm{~mm}$ \\
& Tipe & A \\
& Kecepatan linier & $2,75 \mathrm{~m} / \mathrm{s}$ \\
\hline
\end{tabular}




\section{KESIMPULAN}

Dari hasil rancang bangun sistem pemadatan mesin press batako dapat ditarik kesimpulan sebagai berikut:

1. Menggunakan motor listrik 2HP dengan kecepatan 700rpm .

2. Menggunakan pulli dengan diameter 3inc dan 3inc

3. Menggunakan vbelt tipe A degan panjang $762 \mathrm{~cm}$

4. Waktu yang dibutuhkan dalam pengerjaan adalah 493 menit

5. Waktu yang dibutuhkan dalam proses finishing adalah 60 menit

6. Waktu yang dibutuhkan dalam proses perakitan adalah 210 menit

7. Total biaya yang dikeluarkan adalah Rp. 6.125.200

8. Sistem pemadatan ini mampu memadatkan 10 buah batako dalam 1 kali prosesnya

\section{DAFTAR PUSTAKA}

[1] Nanang Budi Sriyanto, Sugeng Ariyono, Heru Saptono, 2014. Rancang Bangun Mesin Pencetak Paving Block Dengan Sistem Vibrator Untuk Meningkatkan Peningkatan produksi paving UKM. Staf pengajar jurusan Teknik Mesin Politeknik Negeri Semarang

[2] Bambang Singgih Hardjuno, Bambang Tjahjono, Bono, Carli, Nanang Budi Sriyanto, 2013. Rancang Bangun Mesin Pencetak Paving Block Dengan Kapasitas 7 Buah Paving Block Tiap Pengepresan. Jurusan Teknik Mesin, Politeknik Negeri Semarang

[3] Widodo, Willy Kasim, 2014. Pembuatan Mesin Pencetak Dan Uji Penyerapan Air Pada Batako dengan Sistem Injak. Politeknik Negeri Batam

[4] Fadwah Maghrufah, Sulis Yulianto, 2016. Optimasi Rancang Bangun Alat Pemeras Sari Buah Jeruk Dengan Menggunakan Motor Berdaya 132 Watt. Jurusan teknik Mesin, Universitas Muhammadiyah Jakarta

[5] M Kabib, L Batan, I Made, B Pramujat, A Sigit Pramono, 2015, Analisa Pemodelan dan Simulasi Gerak Aktuator Punch Pada Mesin Pres untuk Proses Deep Drawing, Proseding Seminar Nasional Tahunan Teknik Mesin XIV (SNTTM XIV) 15 (UNLAM), 6

[6] Taufiq, Rochim. (1993). Teori dan teknologi Proses Pemesinan. Higher Education Development Support Project 